\title{
Multiscale spatial planning to maintain forest connectivity in the Argentine Chaco in the face of deforestation
}

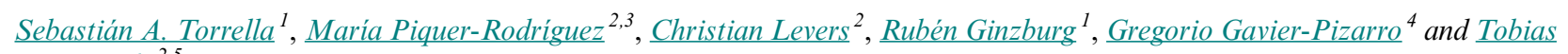 \\ Kuemmerle $^{2,5}$
}

\begin{abstract}
Agricultural expansion threatens biodiversity due to habitat loss and fragmentation. In the Gran Chaco, a global deforestation hotspot, rampant cropland and pasture expansion raise concerns about the sustainability of these land-use changes. Zoning policies were recently enacted in the Argentine Chaco to balance agriculture and conservation, yet the environmental outcomes of implementing these policies remain unclear. Here, we focused on the province of Formosa (Argentina) to evaluate how fully implementing zoning there would affect forest loss and connectivity, and how multiscale landscape planning could enhance environmental outcomes. Specifically, we simulated potential future forest cover for different spatial planning scenarios to assess the effect of (a) implementing regional corridors and (b) enacting additional policies to minimize forest fragmentation at the plot level, under both high and low deforestation rates. We then quantified forest connectivity and fragmentation using morphological image segmentation and landscape indices. Our results show that implementing regional corridors reduced the extent of potential deforestation by 650,000 ha $(43 \%)$, and this alone strongly increased forest connectivity compared with scenarios without corridors. However, how deforestation would be carried out at the plot level was critically important. Plot-level spatial planning could have a strong and positive effect on mitigating fragmentation and on maintaining connectivity, even in scenarios with high deforestation rates (i.e., reducing the number of forest fragments by up to $35 \%$, increasing the core forest by up to $6 \%$ ). Moreover, under high deforestation rates, implementing regional corridors and plot-level design had a strong complementary effect on mitigating forest fragmentation ( $17 \%$ less forest fragments than when implementing either of the two strategies alone). Our analyses clearly highlight the opportunities of multiscale spatial planning and the need to complement broad-scale zoning with plot-level landscape design in order to mitigate the negative impacts of deforestation in the Chaco and other active agricultural frontiers.
\end{abstract}

Key Words: agricultural expansion frontiers; corridors; deforestation; forest law; fragmentation; Gran Chaco; landscape planning.

\section{INTRODUCTION}

The loss and fragmentation of forest habitat due to agricultural expansion is a major threat to biodiversity globally (Foley et al. 2005, Lindenmayer and Fischer 2006, Maxwell et al. 2016). Agricultural expansion into natural forests has various direct and indirect effects on biodiversity, including habitat loss and fragmentation, reduced habitat quality via edge effects in remaining forest fragments, and increased isolation between these fragments (Lindenmayer and Fischer 2006). Forest fragmentation also interacts with other human pressures (e.g., logging, hunting, or fire), often increasing their negative impact on biodiversity (Laurance et al. 2011). Thus, avoiding forest fragmentation and maintaining connectivity are conservation priorities to protect forest biodiversity and associated livelihoods (Vos et al. 2008, Lindenmayer et al. 2012).

An important planning tool to avoid unwanted outcomes from land-use change is zoning (Lambin et al. 2014, Laurance et al. 2014). The most restrictive zoning is the total exclusion of land use (e.g., through strictly protected areas), whereas less restrictive zoning might prohibit some land-use changes (e.g., agricultural expansion into forests) or land-use practices (e.g., logging), but allow others (e.g., firewood collection). The question of how conservation and agricultural land use should be aligned is also at the heart of the recent debate about land sparing vs. land sharing (Green et al. 2005). The former assumes that intensive agriculture combined with large conservation areas minimizes trade-offs between biodiversity and agriculture best, whereas the latter, land sharing, assumes that multiuse landscapes combined with less extensive protected areas are better (Fischer et al. 2011, Phalan et al. 2011, Tscharntke et al. 2012, Bustic and Kuemmerle 2015).

Although protected areas, whether strict or multiuse, are important for halting deforestation and biodiversity loss in agricultural expansion frontiers (Bruner et al. 2001), they tend to become isolated over time, which may undermine their effectiveness in the long run (Newmark 2008, Matteucci and Camino 2012, Melo et al. 2013). A central goal of conservation and land-use planning is therefore to maintain connectivity, ideally at different spatial scales (Poiani et al. 2000). For example, regional-scale corridors that connect large habitat complexes can promote movement and exchange among large mammal populations and allow species to migrate and adapt to environmental change (e.g., Rabinowitz and Zeller 2010, Martinez Pardo et al. 2017). Local-scale spatial planning (i.e., at the plot level) oriented to maintain larger habitat blocks and to maximize connectivity at this scale can help prevent edge effects

\footnotetext{
${ }^{1}$ Grupo de Estudios de Sistemas Ecológicos en Ambientes Agrícolas - Departamento de Ecología, Genética y Evolución - Facultad de Ciencias Exactas y Naturales-Universidad de Buenos Aires, Argentina, ${ }^{2}$ Geography Department, Humboldt-University Berlin, Unter den Linden 6,10099 Berlin, Germany, ${ }^{3}$ Instituto de Ecología Regional (IER-CONICET), Universidad Nacional de Tucumán, Tucumán, Argentina, ${ }^{4}$ Instituto Nacional de Tecnología Agropecuaria (INTA), Instituto de Recursos Biológicos - Centro de Investigación en Recursos Naturales (CIRN-IRB), Hurlingham (Buenos Aires), Argentina, ${ }^{5}$ Integrative Research Institute on Transformations of Human-Environment Systems (IRI THESys), HumboldtUniversity Berlin, Unter den Linden 6, 10099 Berlin, Germany
} 
and facilitate dispersal (Mabry and Barret 2002). Considering connectivity at different spatial scales is therefore important (Fahrig 2002, Pardini et al. 2010, Villard and Metzger 2014), but is rarely considered when zoning plans are designed and implemented. Likewise, discussions about the advantages and disadvantages of land sparing and land sharing strategies (e.g., for well-being or biodiversity conservation) often disregard that the spatial scale at which these strategies are implemented is crucial (Grau et al. 2013, Fischer et al. 2014) and that strategies targeting multiple spatial scales could be particularly beneficial (Ekroos et al. 2016).

Simulating alternative land-use scenarios allows exploration of the potential outcomes of different management policies or actions. Thus, such simulations provide a powerful means to evaluate the impact and effectiveness of alternative landscape design strategies a priori (Piquer-Rodríguez et al. 2015), yet landuse simulations are rarely used for this purpose.

The tropical dry forests and savannas of South America, such as the Chaco, Cerrado, or Llanos, are understudied global hotspots of agricultural expansion (Hansen et al. 2013, Parr et al. 2014). Especially in the Chaco, agriculture (croplands and cultivated pastures) has expanded rapidly in the last decades. For example, by 2013 , about $18 \%$ of all Chaco forest present in 1985 had been converted to agriculture (Baumann et al. 2016), and land-use change continues unabated. In the Argentine Chaco, agricultural expansion resulted in the loss of almost 6 million hectares (Mha) of forest between 1977 and 2010 (Piquer-Rodriguez et al. 2015), and an additional 1 Mha between 2012 and 2016 (Unidad de Manejo del Sistema de Evaluación Forestal (UMSEF) 2017). Deforestation substantially affected the spatial configuration of remaining forests, generally by increasing fragmentation and decreasing connectivity (Gasparri and Grau 2009, Carranza el al. 2015, Piquer-Rodríguez et al. 2015). Changes in forest area and configuration have strong negative impacts on a wide range of taxa, including fungi, birds, mammals, and plants (Grilli et al. 2012, Torres et al. 2014, Nuñez-Regueiro et al. 2015, Torrella et al. 2015), as well as on carbon storage (Baumann et al. 2016, Villarino et al. 2017), air quality (Sacchi et al. 2017), and crop pollination (Monasterolo et al. 2015). Clearly, there is an urgent need to implement conservation and land-use planning in the Chaco to lessen these negative externalities (Kuemmerle et al. 2017).

Recognizing this need, the Argentinean Parliament enacted National Law \#26.331 ("Ley de Presupuestos Mínimos de Protección Ambiental de los Bosques Nativos," hereafter referred to as the "Forest Law") in 2007. The main objectives of this law are (1) to promote forest conservation through land-use planning, (2) to limit deforestation, and (3) to improve and maintain forest functioning and the cultural value of forest. The Forest Law mandates provinces to zone all remaining forests according to their conservation value: category 1 (red) comprises forest areas with "high conservation value" where any productive land use is forbidden. Category 2 (yellow) comprises forest areas with "intermediate conservation value" where deforestation is forbidden, but "sustainable uses" (i.e., some forms of ranching and selective logging, although this differs among provinces) are allowed. Category 3 (green) comprises forest areas in which deforestation (partial or full), cattle ranching, and selective logging are allowed.
The Forest Law, however, remains hotly debated. Controversies are, among others, the result of inconsistent categorization of forest areas between neighboring provinces (García Collazo et al. 2013), power inequalities among different stakeholders (Seghezzo et al. 2011, Silvetti et al. 2013), inefficient funding (Schmidt 2015, Aguiar et al. 2018), forest categorization according to agricultural potential rather than conservation value (Adámoli et al. 2011, Nolte et al. 2017), and ineffectiveness of the current zoning in preventing forest fragmentation (Piquer-Rodríguez et al. 2015). In particular, it is unknown whether the current zoning is effective in preventing, or at least mitigating, unwanted outcomes in terms of forest fragmentation and forest connectivity.

The province of Formosa, in northern Argentina, implemented the Forest Law somewhat differently than other provinces. In addition to the regulations imposed by the national-scale law, Formosa established broadscale corridors, in which deforestation is highly restricted, to link larger forest complexes, and jointly focused on forest and other natural vegetation formations (Formosa Law 1552/10, Piquer-Rodríguez et al. 2015). This provides an excellent opportunity to test the effect of multiscale landscape planning, specifically the relative importance and possible complementarity of broadscale corridors and local-scale spatial planning. Our overarching aim was to use spatial simulations to assess the potential value of the already designated broadscale corridors for maintaining future forest connectivity. Also, we wanted to evaluate whether possible, additional, plotlevel spatial planning could further mitigate fragmentation and improve the connectivity of remaining forest. Specifically, our research questions were:

1. What are the likely effects of the existing regional corridors on the future extent, fragmentation, and connectivity of forest in Formosa province?

2. What are the possible effects of local-scale spatial planning (i.e., at the plot level) on forest fragmentation and connectivity?

3. What are the relative gains of multiscale spatial planning, vs. single-scale, for preventing forest fragmentation and maximizing forest connectivity?

\section{METHODS}

\section{Study area}

The province of Formosa occupies 7.5 Mha in northern Argentina (Fig. 1). Annual precipitation ranges from $>1,400 \mathrm{~mm}$ in the east to $550 \mathrm{~mm}$ in the west, and mean annual temperature is $\sim 23^{\circ} \mathrm{C}$ (Bianchi and Cravero 2010, Unidad Provincial Coordinadora del Agua (UPCA) 2017). The entire province is within the Chaco ecoregion, with natural vegetation communities including different types of forests, as well as savannas, wetlands, and natural grasslands. The two main forest types, according to species composition and physiognomy, are: "tall forest" (bosques altos) and "low forest" (bosques bajos) (see Appendix 1 for a more detailed description of forest types). The extent of agriculture (including both cropland and managed pastures) increased from 250,000 ha in 2001 to 780,000 ha in 2015 , about half of which occurred at the expense of forest (Arriaga Velasco-Aceves 2017). Despite widespread deforestation, Formosa still has 3.2 Mha of remaining forest, which represents about $85 \%$ of the original 
forest cover (Arriaga Velasco-Aceves 2017). The proportion of remaining natural areas is thus higher in Formosa than in other Chaco provinces (Vallejos et al. 2015, Baumann et al. 2016).

Fig. 1. Forest cover and land-use zonation in Formosa province (about 7.5 million hectares) in Northern Argentina. Colors designate zoning categories according to the national Forest Law (in white, nonforest areas). The "Corridor zone" has stricter restrictions on land use, according to the provincial zoning Formosa Law. Inset: location of Formosa Province (black) and the Gran Chaco ecoregion (gray).

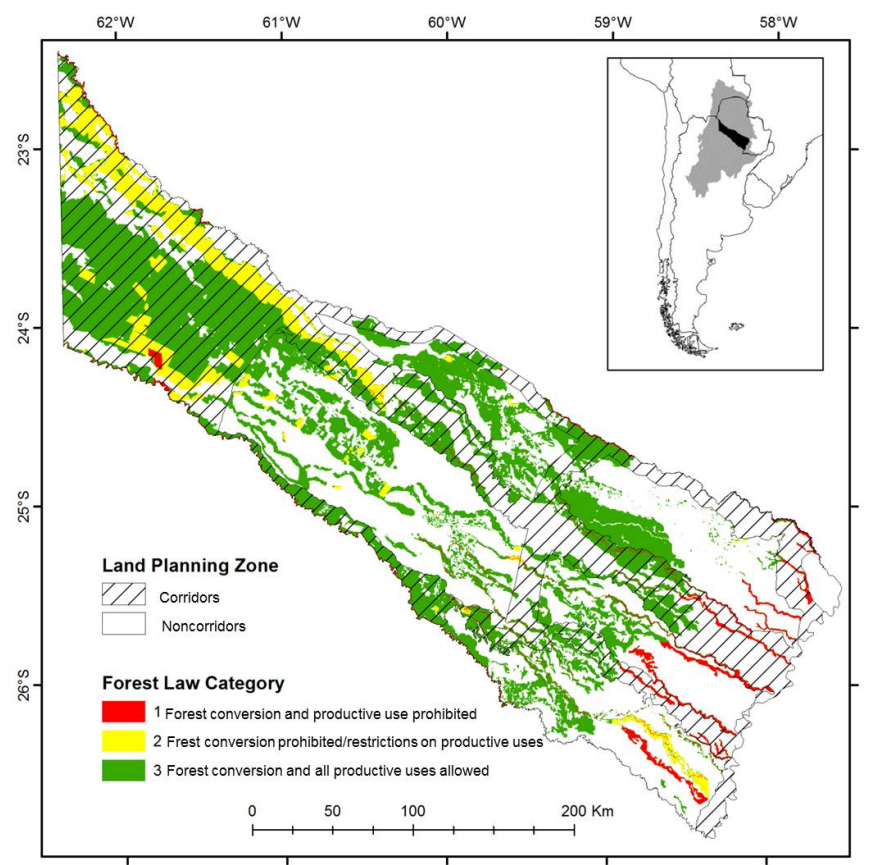

In terms of zoning, and in addition to the general rules of the Forest Law, Formosa enacted its own land-use planning law in 2010 (\#1052, hereafter referred to as the "Formosa Law") to further regulate forest conversion at the level of cadaster plots depending on (1) the plot area, and (2) the share of forest types (i.e., tall or low forest) inside plots (Fig. 1). The Formosa Law divided the province into (1) corridor and (2) noncorridor (i.e., Central and Oriental) zones, with important differences in the allowance of deforestation quotas. Corridors covered nearly $50 \%$ of the province and were designed to include and connect protected areas and other conservation priority areas such as important bird areas (Formosa Provincial Law \#1552/10) (Fig. 1). Land conversions cannot exceed $20 \%$ of the total cadaster plot area in the corridor zone, and $60 \%$ in the noncorridor zone (Fig. 2).

\section{Data sets used}

We used a forest-type map (i.e., tall/low canopy forest) for the year 2015 (Arriaga Velasco-Aceves 2017), which is the most up-to-date and fine-scale forest type map available. The spatial resolution (i.e., pixel size) of this forest-type map was $300 \mathrm{~m}$ (see Appendix 1 for details). We used the cadastral map of Formosa that contains plots with clear land tenure for about $59 \%$ of the province territory. The remaining $41 \%$ of Formosa's territory is not yet parceled and is often occupied legally by people with unclear tenure (e.g., criollos families). As we simulated deforestation at the plot level, for the sake of consistency, we grouped these nonparceled areas into virtual cadastral plots comparable in size to the current land plots (see Appendix 1 for details). By overlaying the maps of forest types, the plot boundaries, and the Formosa Law zoning, we calculated the maximum area allowed for deforestation in each plot, according to the regulations of the Formosa Law.

Fig. 2. Hypothetical example of two cadaster plots in Formosa, (a) inside and (b) outside the "Corridor zone". Each cell represents 1 ha. In the Corridor zone, land conversions cannot exceed $20 \%$ of the total cadaster plot area. Likewise, not more than $10 \%$ of the area covered by tall forest can be deforested and not more than $60 \%$ of the low forests in each cadaster plot can be deforested. Plot (a) with a total of 100 ha contains 50 ha of tall forest and 50 ha of nonforest natural cover (e.g., wetlands or grassland). A landowner can then convert a maximum of 20 ha, of which only 5 ha (i.e., $10 \%$ of 50 ha) can be tall forest. In the "Noncorridor zone", total conversion cannot exceed $60 \%$ of the plot area, with maximum total deforestation of $60 \%$ for both forest types. Thus, in plot (b) up to 60 ha could be converted to agriculture, but only 30 ha of tall forest can be deforested. a. Corridors zone

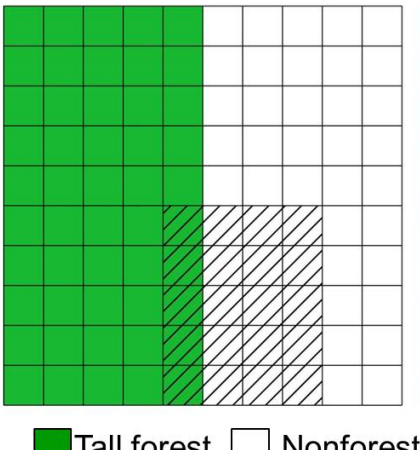

Tall forest

\section{b. Noncorridors zone}

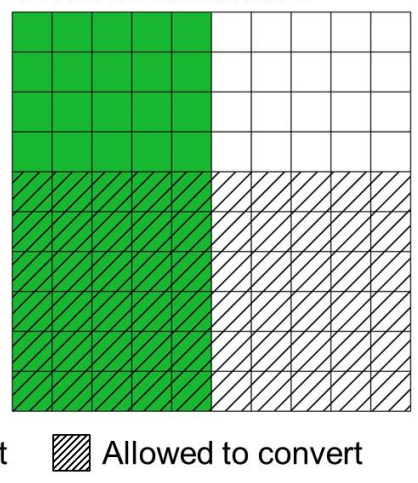

\section{Scenarios and spatial simulations}

We simulated spatial-planning scenarios at two spatial scales, the regional and the plot level. At the regional level, we simulated scenarios with and without corridors to assess the effect of corridor zones as defined by the Formosa Law. For scenarios with corridors, we allowed deforestation per plot as described in Fig. 2 (i.e., less deforestation inside corridors than outside). For scenarios without corridors, we allowed deforestation following the rules specified for the noncorridor zones in the entire study area.

At the plot level, we assessed two modes of how deforestation could be allocated until the maximum deforestation area allowed per plot was reached: (1) randomly or (2) with spatial design to minimize forest fragmentation. For allocation mode 1 (random), we randomly selected the starting location (i.e., pixel) for deforestation within a plot. For allocation mode 2 (design), we first checked if agriculture was already present in the plot. If this was the case, we set deforestation to start from the forest pixel closest to agriculture, in order to minimize forest fragmentation. 
Table 1. Deforestation scenarios simulated for the province of Formosa in the Argentine Chaco

\begin{tabular}{|c|c|c|c|c|c|c|c|c|}
\hline \multirow{3}{*}{$\begin{array}{l}\text { Spatial planning regional level } \\
\text { Spatial planning plot level }\end{array}$} & \multicolumn{4}{|c|}{ Low deforestation rate } & \multicolumn{4}{|c|}{ High deforestation rate } \\
\hline & \multicolumn{2}{|c|}{ With corridors } & \multicolumn{2}{|c|}{ Without corridors } & \multicolumn{2}{|c|}{ With corridors } & \multicolumn{2}{|c|}{ Without corridors } \\
\hline & Design & Random & Design & Random & Design & Random & Design & Random \\
\hline Scenario code & L-C-D & L-C-R & L-NC-D & L-NC-R & H-C-D & H-C-R & H-NC-D & H-NC-R \\
\hline
\end{tabular}

If agriculture was absent in the plot, we set deforestation to start from the center of the cadaster plot in order to minimize connectivity loss between plots and the wider landscape. For both modes, we expanded the deforested area within a plot in a concentric fashion by selecting neighboring forest pixels away from the starting locations, based on distance. In cases where several forest pixels had the same distance to the current deforestation frontier, one of them was selected randomly. For allocation mode 1 , we used more than one deforestation cluster per plot if plots were large. Agricultural plots with more than one cluster occur often in Formosa (authors' observations). We limited the size of the deforestation cluster to 50 ha (for plots up to 500 ha), 200 ha (for plots up to 3,000 ha), and 500 ha (for plots $>3,000 \mathrm{ha})$. Once the maximum size per deforestation cluster was reached, an additional deforestation cluster was created, again starting from a randomly selected location. For allocation mode 2 , deforestation progressed either from the forest-agriculture frontier or the center of the cadaster plot in a single deforestation cluster. For both allocation modes (random and design), we assumed tall forest to be deforested first because they are generally located on better soils (Prado 1993). Only once a plot reached the deforestation quota for tall forest, was low forest then converted.

Overall, our multiscale landscape design setup included four scenarios (i.e., with vs. without corridors plus random vs. design modes), which we simulated for two deforestation rates: high (when the maximum per-plot deforestation allowed by the Formosa Law took place) and low (when only $50 \%$ of the maximum deforestation allowed by the Formosa Law took place). For the latter case, we stratified the province into six strata according to precipitation and land planning zones. Deforestation area was allocated assuming deforestation will continue at current rates (2010-2015), which is reasonable because deforestation has only recently begun in Formosa and much forest can still be converted (for details see Appendix 2). We then selected plots within these strata using stratified random sampling until the deforestation quota at the province level (i.e., 50\% of the maximum deforestation allowed in the Formosa Law) was reached. This resulted in a total of eight scenarios (Table 1). To ensure the robustness of our simulations, we repeated each scenario 50 times to include the effects of random variability within the parameters of each scenario. To implement our deforestation scenarios, we developed an allocation routine in $\mathrm{R}$ (R Core Development Team 2016).

\section{Forest fragmentation and connectivity}

To assess structural forest fragmentation, we used Morphological Spatial Pattern Analysis (MSPA), as implemented in the software GUIDOS 2.5 (Soille and Vogt 2009). MSPA reclassifies forest vs. nonforest maps into seven fragmentation classes: core, edge, islet, perforation, bridge, loop, and branch forest. We set the edge width to one pixel (i.e., $300 \mathrm{~m}$ ), which is a conservative value according to existing empirical work on edge effects in the Chaco (López de Casenave et al. 1995; R. Ginzburg and S. Torrella, unpublished data). For our study, we merged all classes that are connecting landscape elements (bridge, branch, and loop) into a single class. Additionally, we calculated the mean number of forest patches and the mean patch size for each scenario using FRAGSTATS 4.2.1 (McGarigal et al. 2012).

Connectivity is a species-specific concept (Saura et al. 2014), yet can be approximated based on landscape structure (Ernst 2014). Our analysis combined indices of structural connectivity (i.e., spatial configuration of forest patches) and functional connectivity (i.e., species focused), using three complementary indicators. First, we used the CONNECT index, which calculates the proportion of connected patches in the entire landscape given a species-specific threshold dispersal radius. CONNECT is zero when none of the forest patches are connected and 100 when all patches are connected (McGarigal et al. 2012). Second, we used the CLUMPY index (McGarigal et al. 2012), which measures the level of aggregation of forest patches independently of the total forest area (Cushman et al. 2012). CLUMPY ranges from -1 (maximally disaggregated) to 1 (maximally aggregated). CLUMPY and CONNECT were calculated using FRAGSTATS 4.2.1 (McGarigal et al. 2012). Lastly, we used the Equivalent Connected Area (ECA) index, which is network based and defined as the size of a single forest patch that would provide the same value of connectivity as the actual forest pattern in the landscape (Saura et al. 2011). The ECA thus considers the total connected forest area, dispersal flux between forest patches, and the contribution of stepping stones to connectivity (Saura and Rubio 2010). We calculated ECA using CONEFOR 2.6 (Saura and Torné 2009). For CONNECT and ECA, we used a threshold distance of $2 \mathrm{~km}$, according to the home range sizes of intermediate dispersers (e.g., Giant anteater, Myrmecophaga tridactyla) in the Argentine Chaco (Canevari and Vaccaro 2007) because these species would benefit the most from regional connectivity (Piquer-Rodriguez et al. 2015).

Within each scenario, we calculated the standard deviation of each index to assess variability across our replicate runs. Scenarios with high deforestation rates and plot-level design (i.e., H-C-D and H-NC-D, Table 1), in which the location of deforestation was fixed, did not vary and only one simulation was carried out. We tested for the significance of differences between scenarios for each index using $t$ and Mann-Whitney tests (see Appendix 3 for details).

\section{RESULTS}

By definition, our scenarios with corridors and low deforestation rates had less deforestation compared with scenarios without corridors and high deforestation rates. If all deforestation allowed under the current zoning were to be implemented, 850,000 ha of 
Table 2. Deforested area across scenarios (in Mha) and percentage of remaining forest compared with forest extent in 2015. Scenarios differ in deforestation rate (L: low, H: high), spatial planning at the regional level (C: with corridors, NC: without corridors), and spatial planning at the plot level (D: design, R: random)

\begin{tabular}{lcccccccc}
\hline \hline Scenario code & L-C-D & L-C-R & L-NC-D & L-NC-R & H-C-D & H-C-R & H-NC-D & H-NC-R \\
\hline Mean deforested area & 0.41 & 0.42 & 0.41 & 0.41 & 0.85 & 0.87 & 1.49 & 1.52 \\
Deforested area SD & $(0.002)$ & $(0.025)$ & $(0.003)$ & $(0.003)$ & & $(0.00001)$ & 73.0 & $(0.00001)$ \\
Remaining forest (\%) & 87.4 & 87.2 & 87.5 & 87.2 & 73.7 & 73.3 & 54.0 & 53.2 \\
\hline
\end{tabular}

Fig. 3. Forest cover (in green) in Formosa under four scenarios of spatial planning at regional and plot level, and for two deforestation rates. Where replicate runs were carried out, scenarios are exemplified by showing one of these replicate runs.

\section{Low deforestation rate}

Design

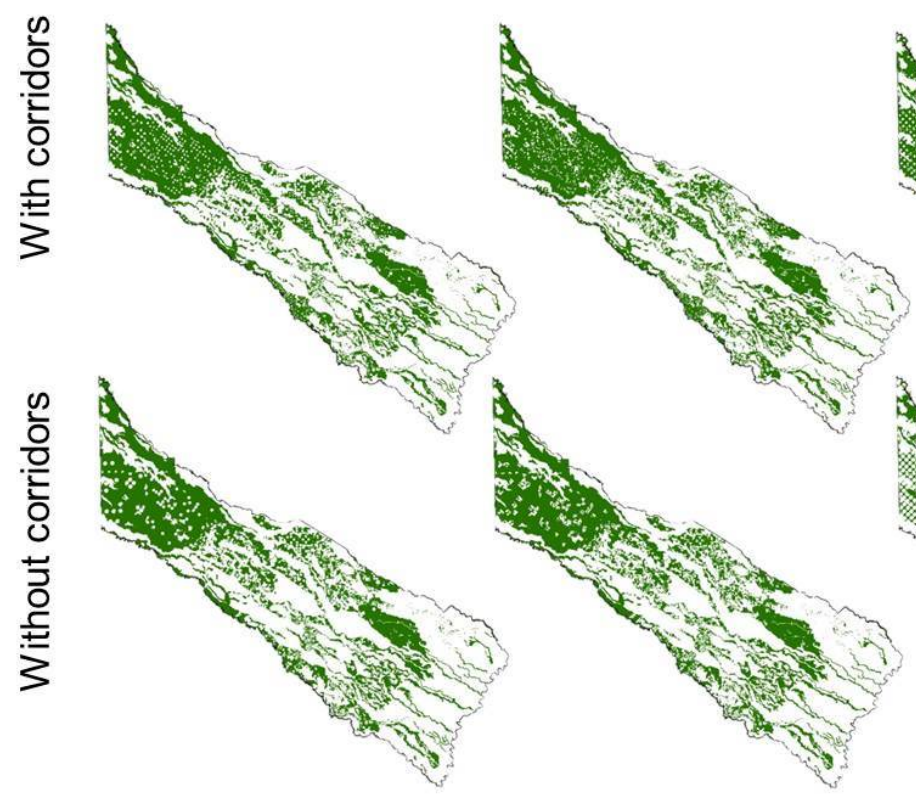

High deforestation rate

Design

Random

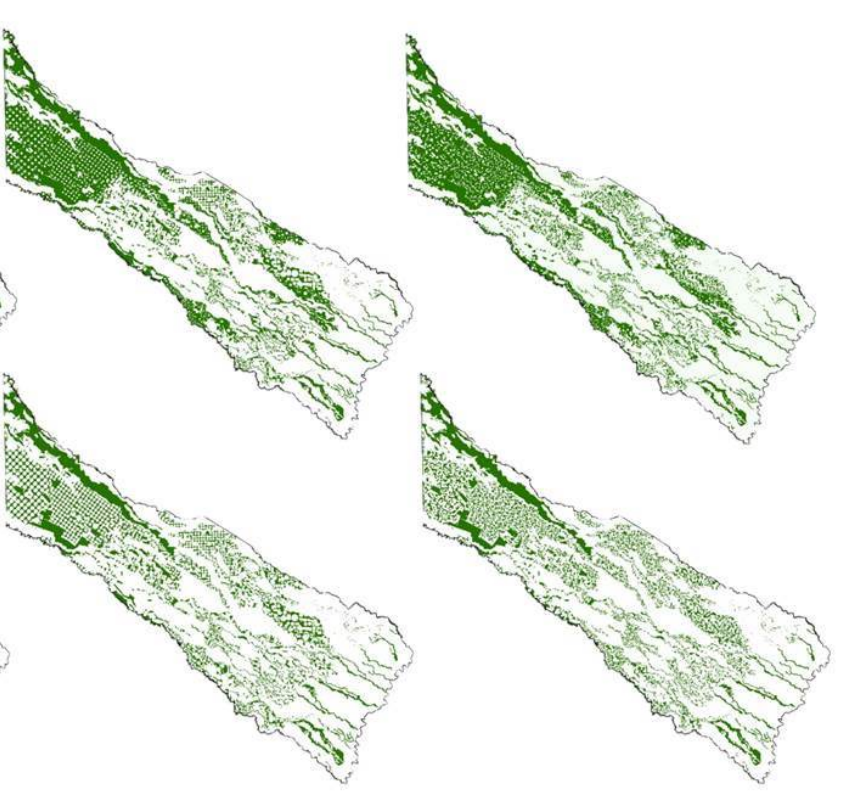

forests would be cleared in Formosa (26\% of all forest in 2015), which would leave a forest cover of $31 \%$ at the province level (Table $2)$. Without the stricter regulations inside corridor zones, an additional 650,000 ha of forest would be lost (Table 2).

Scenarios also differed markedly in terms of deforestation patterns (Fig. 3). High deforestation rates without corridors resulted in small and very dispersed patches of remaining forest, with larger forest patches only preserved in the yellow and red Forest Law categories (Fig. 3). Conversely, scenarios with low deforestation rates and corridors resulted in larger and more continuous forest patches, especially in the west of Formosa province (Fig. 3).

Comparing our scenarios in terms of fragmentation showed varying effects of the regional-level corridors. For low deforestation rates, scenarios with corridors did not differ noticeably from scenarios without corridors; for example in terms of the proportion of core forest (Fig. 4) or patch number (Fig. 5,
Appendix 3), differences were lower than 3\%. This contrasted with results for high deforestation rates, where corridors had a positive and strong effect in reducing fragmentation. For example, when simulating random deforestation at plot level, scenarios with corridors had a higher proportion of core forest (40\%), lower edge forest (27\%, Fig. 4), and less forest patches (37\%, Fig. 5).

The way in which deforestation was allocated at the plot level also had pronounced effects on forest fragmentation (Fig. 4). In our design scenarios, higher proportions of core forest were maintained, and edge and islet forest proportions were reduced compared with the random modes. Interestingly, there were no notable effects on the share of bridge elements. Design at the plot level also resulted in fewer patches (Fig. 5). Differences in fragmentation indices between allocation modes were greater in scenarios with high deforestation rates than in those with low deforestation rates (Fig. 4). 
Fig. 4. Mean (min/max) share of forest area in different fragmentation classes (Bars, left axis) and deforested area (dots, right axis) among the scenarios. Scenarios differ in deforestation rates (L: low, H: high), spatial planning at the regional level (C: with corridors, NC: without corridors), and spatial planning at the plot level (D: design, R: random). Core $=$ interior forest; Edge =outer edge of core forest $(300 \mathrm{~m}$ in our case); Perforation = edge inside core forest patches; Bridge: forest linking forest patches; Islet: small forest patches without core forest.

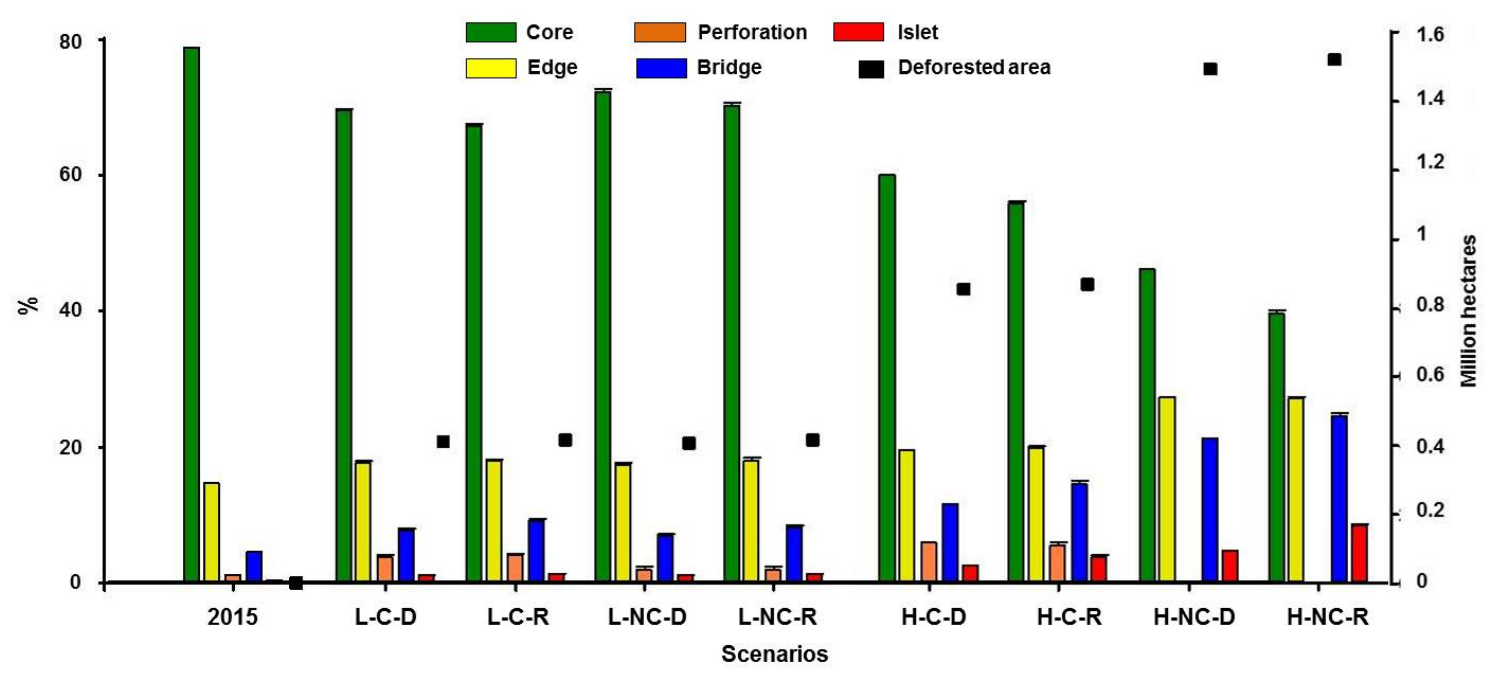

Fig. 5. Mean (min/max) number of patches in simulated scenarios. Scenarios differ in deforestation rate (L: low, $\mathrm{H}$ : high), spatial planning at the regional level (C: with corridors, NC: without corridors) and spatial planning at the plot level (D: design, R: random). Different letters inside the panel represent significant differences ( $p<0.05$, see Appendix 3).

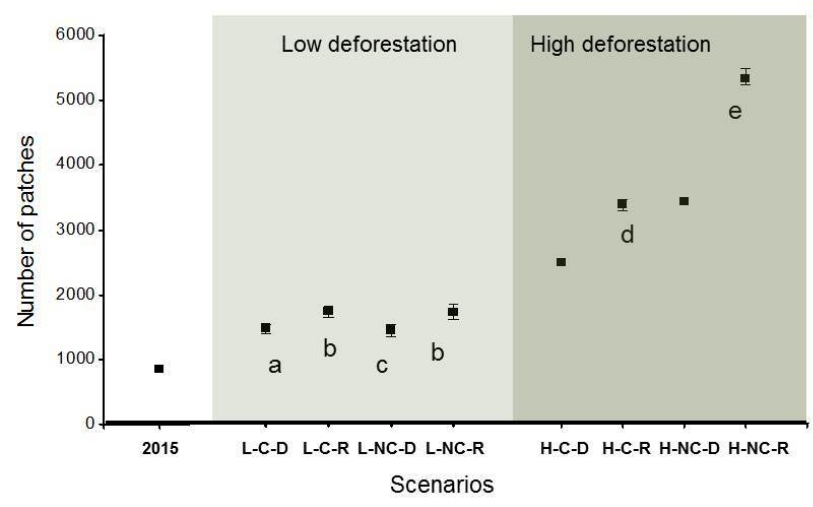

In scenarios with high deforestation rates, the combined effect of planning at both scales (i.e., regional corridors and plot-level design) resulted in less fragmentation than in scenarios for which planning focused on only one of the two scales. For example, in scenarios without corridors and without spatial planning at the plot level, deforestation resulted in $>5,300$ forest patches. Implementing either plot-level design or regional corridors reduced this to about 3,400 patches, but implementing both resulted in $<2,500$ patches (i.e., $26 \%$ reduction in patch numbers; Fig. 5). The effect of plot-level design in reducing fragmentation depended more on the rate of deforestation than on regional-level corridors (Fig. 5). If the deforestation rate was high, the effect of regional-level corridors was greater than that of plot-level design in reducing fragmentation (Fig. 4), whereas the effect of plot-level design was greater than that of regional corridors if the deforestation rate was low. Patch size statistics for each scenario are provided in Appendix 3.

Corridors enhanced connectivity markedly and consistently, for all indices when deforestation rates were high. For low deforestation rates, implementing corridors did not have a strong effect on connectivity, as measured by our indices (Fig. 6a, c), and sometimes even suggested decreasing levels of connectivity (Fig. 6b). Plot-level planning also had a strong effect on connectivity. Scenarios with plot-level design consistently showed higher connectivity compared with scenarios with random deforestation allocation across all indices (Fig. 6, Appendix 3).

Comparing the effect of spatial planning at regional and plot levels suggested that plot-level measures had a stronger positive effect on connectivity than regional corridors in scenarios with low deforestation rate (Fig. 6b, c). In high deforestation scenarios, the effect of plot-level design was substantially greater when there were no corridors implemented at the regional level. For example, ECA rose by $46 \%$ when applying spatial design at the plot level if there were no corridors implemented, but only by $2 \%$ when regional corridors were implemented (Fig. 6c). Under high deforestation rates, notable complementary effects occurred among spatial scales, with markedly higher connectivity values than when implementing planning at one spatial scale only. 
Fig. 6. Mean ( $\min / \max )$ values for forest connectivity indices in Formosa for 2015 and simulated deforestation scenarios. Scenarios differ in deforestation rates (L: low, H: high), spatial planning at the regional level (C: with corridors, $\mathrm{NC}$ : without corridors) and spatial planning at the plot level (D: design, R: random). Different letters inside the panel represent significant differences ( $p<0.05$, see Appendix 3). CONNECT indicates the proportion of distances between patches below a certain threshold ( $2 \mathrm{~km}$ in our case); CLUMPY measures the aggregation of forest patches in the landscape; ECA is the size that a single forest patch should have in order to provide the same amount of reachable forest as the mosaic of forest patches in a given landscape. See text for a complete description of each index.
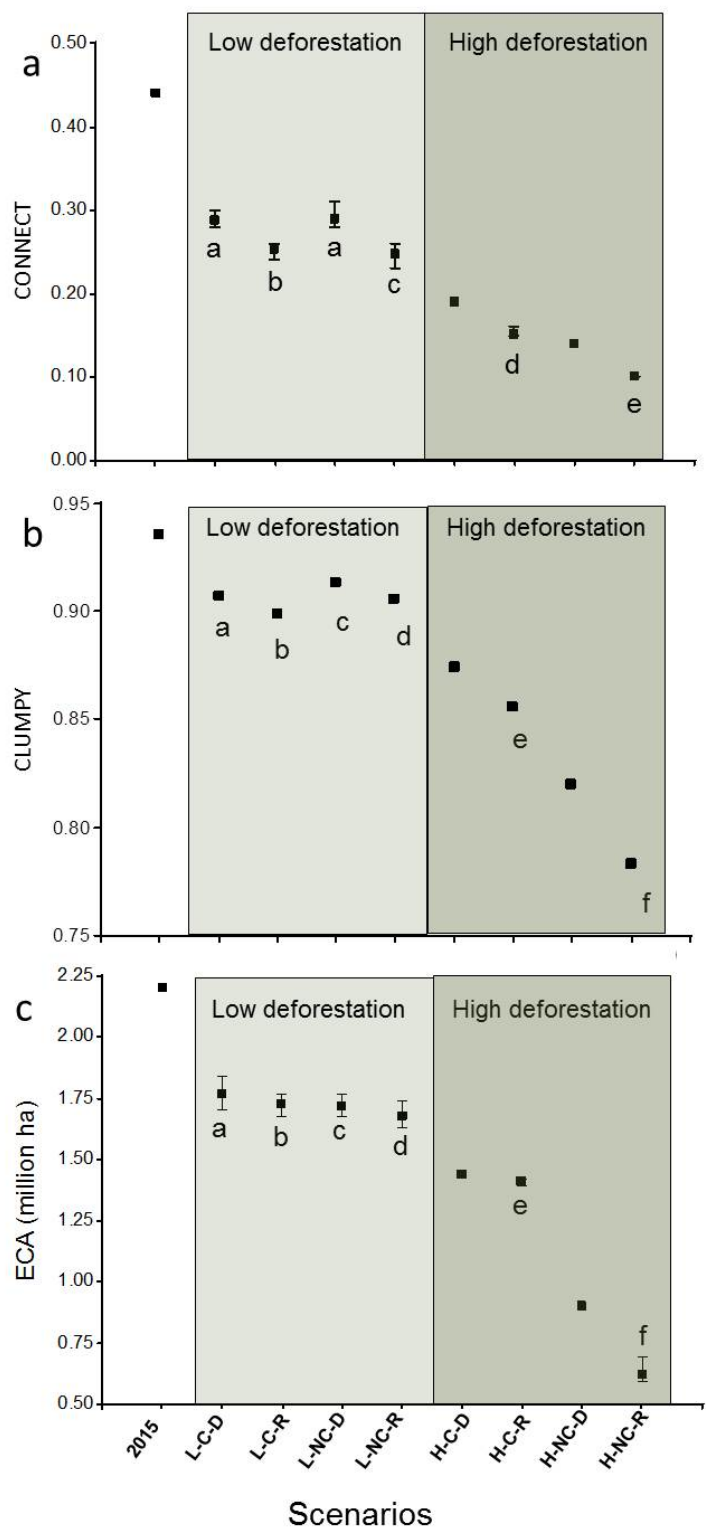

\section{DISCUSSION}

Protecting tropical and subtropical forests and maintaining connectivity among remaining patches is a key conservation goal, yet challenging to achieve in active deforestation frontiers (Lindenmayer et al. 2012, Laurance et al. 2014). Focusing on the Argentine Chaco, a global deforestation hotspot, we assessed how spatial planning at the regional and plot levels may impact forest extent, fragmentation, and connectivity. Our simulations of future forest cover for Formosa province highlight a number of key insights. First, spatial planning at either of the two scales can substantially lessen forest fragmentation and connectivity loss, especially under high deforestation rates. Second, regional and local-level planning had complementary effects. Spatial planning that includes both scales had higher positive effects on forest connectivity than planning at any spatial scale alone, highlighting the benefits of multiscale planning in active deforestation frontiers. Third, the possible effect of planning increased with the rate of deforestation, which is important considering the currently high and increasing deforestation pressures in other parts of the Chaco (e.g., Paraguay) (Baumman et al. 2016) and elsewhere in South America (e.g., the Cerrado) (Noojipady et al. 2017). Finally, plot-level spatial design has a pronounced positive effect in terms of lessening fragmentation and connectivity loss, even under low deforestation rates, suggesting that appropriate policies to foster such plot-level planning should be implemented. Collectively, our analyses clearly highlight the opportunities of multiscale planning to mitigate the impacts of deforestation in the Chaco and other active agricultural frontiers.

\section{Effects of spatial planning on forest fragmentation and connectivity in the Chaco}

Both regional-level and plot-level measures would mitigate forest fragmentation and connectivity loss in the Chaco. Our results show that implementing corridors as foreseen in the Formosa Law would not only result in the conservation of $64 \%$ more forest than without corridors, but would also lead to a more desirable spatial configuration of remaining forests. This highlights the importance of the Formosa Law in addition to the rather general Argentine Forest Law (e.g., García Collazo et al. 2013, Nolte et al. 2017). Plot-level planning, so far not implemented in Argentina, has the potential to mitigate forest fragmentation and connectivity loss substantially, as highlighted by the strong differences in spatial configuration of forest in scenarios with similar deforested area (e.g., scenarios H-C-D vs H-C-R; Fig. 5). This shows that spatial planning can provide opportunities for aligning conservation and production goals.

In low-deforestation scenarios, corridors did not necessarily improve forest connectivity, and some scenarios without corridors had higher forest connectivity than scenarios with corridors. This surprising result can be explained by the fact that less deforestation inside corridors is allowed at the plot level than outside corridors. As a consequence, to reach the same area of deforestation in both scenarios (with or without corridors), the spatial simulation requires deforestation in more plots in scenarios with corridors. This translates into a more patchy forest pattern, and thus slightly higher fragmentation, in corridor scenarios and more compact forest patches, and thus slightly less fragmented, in noncorridor scenarios. Yet, these differences were small for all indices we tested. 
Combining planning measures at both spatial scales resulted in more connected and less fragmented forest than when applying either option in isolation. This was particularly the case in our high deforestation scenarios, as shown by all indices, except ECA (e.g., scenarios H-C-D vs. H-NC-D or H-C-R; Fig. 6). This result is interesting because other outcomes of this multiscale experiment are possible (e.g., the two strategies could have been redundant). This highlights the benefits that multiscale approaches could provide to land-use planning in active agriculture frontiers. Particularly, in the Argentine Chaco, multiple biodiversity benefits are likely. For example, reducing the proportion of edge forest would lessen structural changes in forest canopies (López de Casenave et al. 1995) and community turnover in birds (López de Casenave et al. 1998). Also, maintaining connectivity at a regional level is crucial for the viability of mammals (Quiroga et al. 2014, Periago et al. 2015), and the spatial configuration of forest is an important determinant of mammal habitat (Nuñez-Regueiro et al. 2015).

The mitigating and complementary effects of planning at both spatial scales were stronger for scenarios with high deforestation rates than for those with lower deforestation rates. Formosa province still has relatively high forest cover, and even under high deforestation, remaining forest cover would amount to $31 \%$. This underlines that spatial planning could have stronger effects in zones where intermediate levels of forest remain compared with areas with higher forest cover, where connectivity is already high. This finding seems important for many regions in the Chaco, where deforestation has substantially reduced forest cover recently (Vallejos et al. 2015, Baumann et al. 2016). The impact of planning for connectivity could be similarly large in other ecoregions of South America, where agriculture expansion is causing major forest losses, such as the Cerrado (Noojipady et al. 2017), the Llanos, and the Atlantic forest (Ribeiro et al. 2009). Yet, our results do not imply that corridors have no effects on connectivity until the maximum deforestation levels are reached, which could lead to an oversimplification of the landscape (van der Hoek et al. 2015). It would be necessary to test intermediate deforestation levels to assess when corridors start to be relevant.

Plot-level planning had a strong effect on lessening fragmentation and connectivity loss, even in low deforestation scenarios, where it was greater than the effect of corridors. This effect increased as forest area decreased, showing that the importance of connectivity is highest in landscapes with intermediate amounts of habitat (Pardini et al. 2010, Villard and Metzger 2014). Thus, our findings also suggest that planning implemented at the plot level can influence the connectivity of the forest at broader scales. Such planning is already done in the Brazilian Amazon (Forest Code) and to some extent in the Paraguayan Chaco, where minimum shares of forest per property have to remain. Even the Argentinean Forest Law foresees similar planning tools, as there are some spatial deforestation restrictions (e.g., on steeper slopes in Chaco and Salta, according to distance to rivers or forest type in Formosa). Yet, we know of no example where plot-level planning specifically targeted to enhance connectivity is already in place. It would therefore be beneficial to explore policy instruments to implement planning that takes into account forest configuration within plots and in relation to neighboring plots, for example by adopting zoning laws or incentives in Argentina. This would, however, require a coordinated intraprovincial planning effort that might be challenging under a decentralized planning system such as in Argentina (Seghezzo et al. 2011, Piquer-Rodriguez et al. 2015, Nolte et al. 2017).

Harmonizing agriculture production and conservation in places like the Chaco is a complex challenge. Although our study did not directly assess the trade-off between conservation and agriculture, there are interesting lessons learned from our work that might be relevant for discussions, such as whether land sparing or sharing provides lower trade-offs. Importantly, our work highlights that there are clear benefits of multiscale spatial planning and that trade-offs may vary with scale, both of which land sparing/sharing discussions typically ignore (Grau et al. 2013, Fischer et al. 2014, Ekroos et al. 2016). Similarly, our study highlights potential unwanted outcomes of forest fragmentation at broader scales, for example, where a local focus on contiguous forest plots leads to a broadscale loss of connectivity (Balmford et al. 2012). Moreover, as others have highlighted, policies to achieve more sustainable outcomes in the Chaco should: assess alternative strategies to increasing agricultural production, such as sustainable intensification (Macchi et al. 2013); consider habitats other than forests, such as wetlands and natural grasslands (Grau et al. 2015); and consider the views and needs of all relevant stakeholders, including minorities (Seghezzo et al. 2011, Silvetti et al. 2013).

\section{Limitations}

Our results should be applied with a clear understanding of the scope and limitations of our study. First, although we used a broad set of complementary connectivity and fragmentation measures, a full assessment of functional connectivity should assess a wide range of dispersal distances or matrix characteristics and human activities. Second, we used relatively simple approaches to allocate plot-level deforestation (random vs. design), which represented two extremes of how deforestation, and thus fragmentation and connectivity, could take place. Therefore, forest configurations other than those considered in our simulations are also possible and might be beneficial for maximizing connectivity (e.g., Balmford et al. 2012). Yet, the concentric deforestation patterns simulated here are plausible for the Chaco and do occur (e.g., near Nueva Esperanza, Santiago del Estero Province, 26.1 ${ }^{\circ} \mathrm{S}, 63^{\circ} \mathrm{WW}$ ). Third, assessing the effect of corridors is challenging because corridor scenarios always entail more forest than scenarios without corridors, and observed differences in connectivity could thus be caused by differences in remaining forest area. Nevertheless, we used the CLUMPY index (Cushman et al. 2012) because it is area independent (i.e., it mainly depends on forest configuration, not forest area). Additionally, we weighted the ECA-index by the total remaining forest area in the province to emphasize the configuration aspect of this index (Herrera et al. 2017). Yet, we found the same patterns for the ECA-index and the weighted ECA-index. Finally, during the work on this manuscript, the Formosa Law was revised (1060/18) and 81,700 ha of forest were zoned into categories 1 or 2 , where deforestation is prohibited. This is positive from a forest conservation perspective, but covers only $2.5 \%$ of the total forest area in our analysis, and thus, does not change any of our major conclusions.

\section{Conclusions and implications}

Habitat loss and fragmentation are major threats to biodiversity in the Chaco and other agricultural frontiers in South America 
(The Nature Conservancy (TNC) 2005, Laurance et al. 2014). Our study shows the positive effects that zoning policies in Formosa province could have, in addition to the policies already implemented by the national Forest Law, to mitigate the outcomes of agriculture expansion on forest loss, fragmentation, and connectivity. Moreover, we highlight how forest connectivity could be further enhanced without limiting agricultural expansion in major ways by implementing both regional and local-level spatial planning.

Implementing such multiscale spatial planning would benefit forest connectivity, biodiversity conservation, and local livelihoods in different ways. Clearly, land-use planning to align agriculture and conservation is urgently needed in the Chaco (Kuemmerle et al. 2017). At the moment, there are several governmental initiatives that define regional corridors in the Argentine Chaco (Administración de Parques Nacionales (APN) 2006, Secretaría de Ambiente y Desarrollo Sustentable (SAyDS) 2015), yet none of them is implemented except in Formosa. Corridors in Formosa are based on those proposed by the National Parks Administration (APN 2006), and our study highlights the potentially strong conservation effect that implementing them over a larger area in the Chaco could have. Given that zoning laws and corridor plans are currently discussed and implemented at the provincial level, our analysis also highlights the need for harmonized planning across provincial and national borders (García Collazo et al. 2013, PiquerRodríguez et al. 2015) to maintain connectivity at broader spatial scales. However, legislation targeting plot-level deforestation patterns has yet to emerge in the Chaco. Coupling plot-level spatial design with regional corridor planning had strong effects in improving forest connectivity in our case, and we therefore urge decision makers to explore multiscale strategies in conservation and land-use planning due to the potential benefits these can bring.

Responses to this article can be read online at: http://www.ecologyandsociety.org/issues/responses. php/10546

\section{Acknowledgments:}

We are grateful to J. Adámoli, L. Basterra, E. Law, and H. Bluhm, as well as the "Ministerio de la Producción y Ambiente de la Provincia de Formosa" for help and valuable comments. We also thank the editors and two anonymous reviewers for constructive comments that improved this manuscript. We gratefully acknowledge funding by the German Ministry of Education and Research (BMBF, Project PASANOA, 031B0034A), the German Research Foundation (DFG, Project $K U$ 2458/5-1), and the Ministry of Science, Technology and Innovation of Argentina (Mincyt) (Project PICT 2014-1481).

\section{LITERATURE CITED}

Adámoli, J., R. Ginzburg, and S. A. Torrella. 2011. Escenarios productivos y ambientales del Chaco Argentino. 1977-2010 ed. Fundación Producir Conservando. Buenos Aires. [online] URL: http://producirconservando.org.ar/intercambio/docs/ escenarios_productivos ambientales_chaco.pdf

Administración de Parques Nacionales (APN). 2006. Diseño de una estrategia regional de corredores de conservación en el Gran Chaco Argentino. [online] URL: https://www.sib.gov.ar/archivos/ Doc.Final 1a etapa Pr.CCh +revision RBPDF-1.pdf

Aguiar, S., M. Mastrangelo, M. García Collazo, G. Camba Sans, C. Mosso, L. Ciuffoli, M Schimidt, M. Vallejos, L. Langbehn, D. Cáceres, G. Merlinsky, J. Paruelo, L. Seghezzo, L. Staiano, M. Texeira, J. Volante, and S. Verón. 2018. ¿Cuál es la situación de la Ley de Bosques en la Región Chaqueña a diez años de su sanción? Revisar s pasado para discutir su futuro. Ecología Austral 28:400-417. http://dx.doi.org/10.25260/EA.18.28.2.0.677

Arriaga Velasco-Aceves, P. 2017. Expansión agropecuaria en la Provincia de Formosa: pérdida de ambientes naturales y fragmentación de bosques entre 2001 y 2015. Thesis. Facultad de Ciencias Exactas y Naturales, Universidad de Buenos Aires, Argentina.

Balmford, A., R. Green, and B. Phalan. 2012. What conservationists need to know about farming. Proceedings of the Royal Society B: rspb20120515. http://dx.doi.org/10.1098/ rspb.2012.0515

Baumann, M., I. Gasparri, M. Piquer-Rodríguez, G. Gavier Pizarro, P. Griffiths, P. Hostert, and T. Kuemmerle. 2016. Carbon emissions from agricultural expansion and intensification in the Chaco. Global Change Biology 23: 1902-1916. http://dx.doi. org/10.1111/gcb.13521

Bianchi, A., and S. Cravero. 2010. Atlas climático digital de la República Argentina. Instituto Nacional de Tecnología Agropecuaria. [online] URL: http://inta.gob.ar/documentos/ atlas-climatico-digital-de-la-republica-argentina

Bruner, A. G., R. E. Gullison, R. E. Rice, and G. A. Fonseca. 2001. Effectiveness of parks in protecting tropical biodiversity. Science 291:125-128. http://dx.doi.org/10.1126/science.291.5501.125

Butsic, V., and T. Kuemmerle. 2015. Using optimization methods to align food production and biodiversity conservation beyond land sharing and land sparing. Ecological Applications 25:589595. http://dx.doi.org/10.1890/14-1927.1

Canevari, M., and O. Vaccaro. 2007. Guía de mamíferos del sur de América del Sur. Editorial LOLA, Buenos Aires, Argentina.

Carranza, M., L. Hoyos, L. Frate, A. Acosta, and M. Cabido. 2015. Measuring forest fragmentation using multitemporal forest cover maps: forest loss and spatial pattern analysis in the Gran Chaco, central Argentina. Landscape and Urban Planning 143:238-247. http://dx.doi.org/10.1016/j.landurbplan.2015.08.006

Cushman, S. A., A. Shirk, and E. L. Landguth. 2012. Separating the effects of habitat area, fragmentation and matrix resistance on genetic differentiation in complex landscapes. Landscape Ecology 27:369-380. http://dx.doi.org/10.1007/s10980-011-9693-0

Ekroos, J., A. Ödman, G. Andersson, K. Birkhofer, L. Herbertsson, B. Klatt, O. Olsson, P. Olsson, A. Persson, H. Prentice, M. Rundlöf, and H. Smith. 2016. Sparing land for biodiversity at multiple spatial scales. Frontiers in Ecology and Evolution 3: 145. http://dx.doi.org/10.3389/fevo.2015.00145 
Ernst, B. W. 2014. Quantifying landscape connectivity through the use of connectivity response curves. Landscape Ecology 29:963-978. http://dx.doi.org/10.1007/s10980-014-0046-7

Fahrig, L. 2002. Effect of habitat fragmentation on the extinction threshold: a synthesis. Ecological Applications 12:346-353.

Fischer, J., D. Abson, V. Butsic, M. Chappell, J. Ekroos, J. Hanspach, T. Kuemmerle, H. Smith, and H. Wehrden. 2014. Land sparing versus land sharing: moving forward. Conservation Letters 7:149-157. http://dx.doi.org/10.1111/conl.12084

Fischer, J., P. Batáry, K. Bawa, L. Brussaard, M. Chappell, Y. Clough, G. Daily, J. Dorrough, T. Hartel, L. Jackson, A. Klein, C. Kremen, T. Kuemmerle, D. Lindenmayer, H. Mooney, I. Perfecto, S. Philpott, T. Tscharntke, J. Vandermeer, T. Wanger, and H. von Wehrden. 2011. Conservation: limits of land sparing. Science 334:593-593. http://dx.doi.org/10.1126/science.334.6056.593a

Foley, J., R. DeFries, G. Asner, C. Barford, G. Bonan, S. Carpenter, F. Chapin, M. Coe, G. Daily, H. Gibbs, J. Helkowski, T. Holloway, E. Howard, C. Kucharik, C. Monfreda, J. Patz, C. Prentice, N. Ramankutty, and P. Snyde. 2005. Global consequences of land use. Science 309:570-574. http://dx.doi. org/10.1126/science. 1111772

García Collazo, M., A. Panizza, and J. Paruelo. 2013. Ordenamiento Territorial de Bosques Nativos: Resultados de la Zonificación realizada por provincias del Norte argentino. Ecología austral 23:97-107.

Gasparri, I., and H. Grau. 2009. Deforestation and fragmentation of Chaco dry forest in NW Argentina (1972-2007). Forest Ecology and Management 258:913-921. http://dx.doi.org/10.1016/j. foreco.2009.02.024

Grau, R., T. Kuemmerle, and L. Macchi. 2013. Beyond "land sparing versus land sharing": environmental heterogeneity, globalization and the balance between agricultural production and nature conservation. Current Opinion in Environmental Sustainability 5:477-483. http://dx.doi.org/10.1016/j.cosust.2013.06.001

Grau, H. R., R. Torres, N. I. Gasparri, P. G. Blendinger, S. Marinaro, amd L. Macchi. 2015. Natural grasslands in the Chaco. A neglected ecosystem under threat by agriculture expansion and forest-oriented conservation policies. Journal of Arid Environments 123:40-46. http://dx.doi.org/10.1016/j.jaridenv.2014.12.006

Green, R., S. Cornell, J. Scharlemann, and A. Balmford. 2005. Farming and the fate of wild nature. Science 307:550-555. http:// dx.doi.org/10.1126/science. 1106049

Grilli, G., C. Urcelay, and L. Galetto. 2012. Forest fragment size and nutrient availability: complex responses of mycorrhizal fungi in native-exotic hosts. Plant Ecology 213:155-165. http://dx.doi. org/10.1007/s11258-011-9966-3

Hansen M., P. Potapov, R. Moore, M. Hancher, S. Turubanova, A. Tyukavina, D. Thau, S. Stehman, S. Goetz, T. Loveland, A. Kommareddy, A. Egorov, L. Chini, C. Justice, and J. Townshend. 2013. High-resolution global maps of 21st century forest cover change. Science 342:850-853. http://dx.doi.org/10.1126/science.1244693

Herrera, L., M. Sabatino, A. Gastón, and S. Saura. 2017. Grassland connectivity explains entomophilous plant species assemblages in an agricultural landscape of the Pampa Region, Argentina. Austral Ecology 42:486-496. http://dx.doi.org/10.1111/ $\underline{\text { aec. } 12468}$

Kuemmerle, T., M. Altrichter, G. Baldi, M. Cabido, M. Camino, E. Cuellar, R. L. Cuellar, J. Decarre, S. Dí, I. Gasparri, G. GavierPizarro, R. Ginzburg, A. J. Giordano, H. R. Grau, E. Jobbágy, G. Leynaud, L. Macchi, M. Mastrangelo, S. D. Matteucci, A. Noss, J. Paruelo, M. Piquer-Rodríguez, A. Romero-Muñoz, A. Semper-Pascual, J. Thompson, S. Torrella, R. Torres, J. N. Volante, A. Yanosky, and M. Zak. 2017. Forest conservation: remember Gran Chaco. Science 355:465-465. http://dx.doi. org/10.1126/science.aal3020

Lambin, E. F., P. Meyfroidt, X. Rueda, A. Blackman, J. Börner, P. O. Cerutti, T. Dietsch, L. Jungmann, P. Lamarque, J. Lister, N. F. Walker, and S. Wunder. 2014. Effectiveness and synergies of policy instruments for land use governance in tropical regions. Global Environmental Change 28:29-140. http://dx.doi. org/10.1016/j.gloenvcha.2014.06.007

Laurance, W. F., J. L. Camargo, R. C. Luizão, S. G. Laurance, S. L. Pimm, E. M. Bruna, P. C. Stouffer, G. B. Williamson, J. Ben237; tez-Malvido, H. L. Vasconcelos, K. S. van Houtan, C. E. Zartman, S. A. Boyle, R. K. Didham, A. Andrade, and T. E. Lovejoy. 2011. The fate of Amazonian forest fragments: a 32-year investigation. Biological Conservation 144:56-67. http://dx.doi.org/10.1016/j. biocon.2010.09.021

Laurance, W., J. Sayer, and K. Cassman. 2014. Agricultural expansion and its impacts on tropical nature. Trends in Ecology and Evolution 2:107-116. http://dx.doi.org/10.1016/j.tree.2013.12.001

Lindenmayer, D., S. Cunningham, and A. Young. 2012. Perspectives on land use intensification and biodiversity conservation. Pages 123-134 in D. Lindenmayer, S. Cunningham, and A. Young, editors. Land use intensification: effects on agriculture, biodiversity and ecological processes. CRC Press, Boca Raton, Florida, USA.

Lindenmayer, D., and J. Fischer. 2006. Habitat fragmentation and landscape change: an ecological and conservation synthesis. Island Press, Washington, D.C., USA.

López de Casenave, J. L., J. P. Pelotto, S. M. Caziani, M. Mermoz and J. Protomastro. 1998. Responses of avian assemblages to a natural edge in a Chaco semiarid forest in Argentina. The Auk 115:425-435. http://dx.doi.org/10.2307/4089201

López de Casenave, J. L., J. P. Pelotto, and J. Protomastro. 1995. Edge-interior differences in vegetation structure and composition in a Chaco semi-arid forest, Argentina. Forest Ecology and Management 72:61-69. http://dx.doi.org/10.1016/0378-1127(94) 03444-2

Mabry, K., and G. Barrett. 2002. Effects of corridors on home range sizes and interpatch movements of three small mammal species. Landscape Ecology 17:629-636. http://dx.doi.org/10.1023/ A:1021545419534

Macchi, L., H. R. Grau, P. V. Zelaya, and S. Marinaro. 2013. Trade-offs between land use intensity and avian biodiversity in the dry Chaco of Argentina: a tale of two gradients. Agriculture, Ecosystems and Environment 174:11-20. http://dx.doi.org/10.1016/ j.agee.2013.04.011 
Martinez Pardo, J., A. Paviolo, S. Saura, and C. De Angelo. 2017. Halting the isolation of jaguars: where to act locally to sustain connectivity in their southernmost population. Animal Conservation 20(6):543-554. http://dx.doi.org/10.1111/acv.12354

Matteucci, S. D., and M. Camino. 2012. Protected areas isolation in the Chaco Region, Argentina. Journal of Geography and Geology 4(3): 15. http://dx.doi.org/10.5539/jgg.v4n3p15

Maxwell, S., R. Fuller, T. Brooks, and J. Watson. 2016. Biodiversity: the ravages of guns, nets and bulldozers. Nature 536:143-145. http://dx.doi.org/10.1038/536143a

McGarigal K., S. A. Cushman, and E. Ene. 2012. FRAGSTATS v4: spatial pattern analysis program for categorical and continuous maps. University of Massachusetts, Amherst, Massachusetts, USA.

Melo, F., V. Arroyo-Rodríguez, L. Fahrig, M. Martínez-Ramos, and M. Tabarelli. 2013. On the hope for biodiversity-friendly tropical landscapes. Trends in Ecology and Evolution 28:462-468. http://dx.doi.org/10.1016/j.tree.2013.01.001

Monasterolo, M., M., Musicante, G. Valladares, and A. Salvo. 2015. Soybean crops may benefit from forest pollinators. Agriculture, Ecosystems and Environment 202:217-222. http://dx. doi.org/10.1016/j.agee.2015.01.012

Newmark, W. D. 2008. Isolation of African protected areas. Frontiers in Ecology and the Environment 6:321-328. http://dx.doi. org/10.1890/070003

Nolte, C., B. Gobbi, Y. de Waroux, M. Piquer-Rodríguez, V. Butsic, and E. Lambin. 2017. Decentralized land use zoning reduces large-scale deforestation in a major agricultural frontier. Ecological Economics 136:30-40. http://dx.doi.org/10.1016/j. ecolecon.2017.02.009

Noojipady, P., M. C. Morton, N. M. Macedo, C. D. Victoria, C. Huang, K. H. Gibbs, and L. E. Bolfe. 2017. Forest carbon emissions from cropland expansion in the Brazilian Cerrado biome. Environmental Research Letters 12(2): 025004. http://dx. doi.org/10.1088/1748-9326/aa5986

Núñez-Regueiro, M., L. Branch, R. Fletcher, G. Marás, E. Derlindati, and A. Tálamo. 2015. Spatial patterns of mammal occurrence in forest strips surrounded by agricultural crops of the Chaco region, Argentina. Biological Conservation 187:19-26. http://dx.doi.org/10.1016/j.biocon.2015.04.001

Pardini, R., A. de Arruda Bueno, T. A. Gardner, P. I. Prado, and J. P. Metzger. 2010. Beyond the fragmentation threshold hypothesis: regime shifts in biodiversity across fragmented landscapes. PloS One 5(10): e13666. http://dx.doi.org/10.1371/ journal.pone.0013666

Parr, C.L., C. E. Lehmann, W. J. Bond, W. A. Hoffmann, and A. N. Andersen. 2014. Tropical grassy biomes: misunderstood, neglected, and under threat. Trends in Ecology and Evolution 29:205-213. http://dx.doi.org/10.1016/j.tree.2014.02.004

Periago, M., V. Chillo, and R. Ojeda. 2015. Loss of mammalian species from the South American Gran Chaco: empty savanna syndrome? Mammal Review 45:41-53.

Phalan B, M. Onial, A. Balmford, and R. Green. 2011. Reconciling food production and biodiversity conservation: land sharing and land sparing compared. Science 333:1289-1291. http://dx.doi.org/10.1126/science.1208742

Piquer-Rodríguez, M., S. A. Torrella, G. Gavier-Pizarro, J. N. Volante, D. Somma, R. Ginzburg, and T. Kuemmerle. 2015. Effects of past and future land conversions on forest connectivity in the Argentine Chaco. Landscape Ecology 30:817-833. http:// dx.doi.org/10.1007/s10980-014-0147-3

Poiani, K.A., B. D. Richter, M. G. Anderson, and H. E. Richter. 2000. Biodiversity conservation at multiple scales: functional sites, landscapes, and networks. BioScience 50:133-146. http://dx. doi.org/10.1641/0006-3568(2000)050[0133:BCAMSF]2.3.CO;2

Prado, D. E. 1993. What is the Gran Chaco vegetation in South America? I: a review. Contribution to the study of flora and vegetaion of the Chaco. Candollea 48:145-172.

Quiroga, V. A., G. I. Boaglio, A. J. Noss, and M. S. Di Bitetti. 2014. Critical population status of the jaguar Panthera onca in the Argentine Chaco: camera-trap surveys suggest recent collapse and imminent regional extinction. Oryx 48:141-148. http://dx. doi.org/10.1017/S0030605312000944

R Core Development Team. 2016. R: a language and environment for statistical computing. R Foundation for Statistical Computing, Vienna, Austria. [online] URL: https://www.R-project.org/

Rabinowitz, A., and K. Zeller. 2010. A range-wide model of landscape connectivity and conservation for the jaguar, Panthera onca. Biological conservation 143:939-945. http://dx.doi. org/10.1016/j.biocon.2010.01.002

Ribeiro, M. C., J. P. Metzger, A. C. Martensen, F. J. Ponzoni, and M. M. Hirota. 2009. The Brazilian Atlantic forest: how much is left, and how is the remaining forest distributed? Implications for conservation. Biological Conservation 142:1141-1153. http://dx. doi.org/10.1016/j.biocon.2009.02.021

Sacchi, L., P. Powell, N. Gasparri, and H. Grau. 2017. Air quality loss in urban centers of the Argentinean Dry Chaco: wind and dust control as two scientifically neglected ecosystem services. Ecosystem Services 24:234-240. http://dx.doi.org/10.1016/j. ecoser.2017.03.006

Saura, S., C. Estreguil, C. Mouton, and M. Rodríguez-Freire. 2011. Network analysis to assess landscape connectivity trends: application to European forests (1990-2000). Ecological Indicators 11:407-416. http://dx.doi.org/10.1016/j.ecolind.2010.06.011

Saura, S., E. Martín-Queller, and M. Hunter. 2014. Forest landscape change and biodiversity conservation. Pages 167-198 in J. C. Azevedo, A. H. Perera, and M. A. Pinto, editors. Forest landscapes and global change. Springer, New York, New York, USA. http://dx.doi.org/10.1007/978-1-4939-0953-7_7

Saura, S., and L. Rubio. 2010. A common currency for the different ways in which patches and links can contribute to habitat availability and connectivity in the landscape. Ecography 33:523537. http://dx.doi.org/https://doi.org/10.1111/j.1600-0587.2009.05760. $\underline{x}$

Saura, S., and J. Torné. 2009. Conefor Sensinode 2.2: a software package for quantifying the importance of habitat patches for landscape connectivity. Environmental Modelling and Software 24:135-139. http://dx.doi.org/10.1016/j.envsoft.2008.05.005 
Schmidt, M. 2015. Recursos naturales y económicos en disputa. Revibec: revista de la Red Iberoamericana de Economia Ecológica 24:139-151.

Secretaría de Ambiente y Desarrollo Sustentable (SAyDS). 2015. Corredores ecológicos para el Chaco Argentino. Definición y pautas metodológicas para su implementación. [online] URL: http:// leydebosques.org.ar/zips/informesoficiales/

Seghezzo, L., J. Volante, J. Paruelo, D. Somma, E. Buliubasich, H. Rodríguez, S. Cagnon and M. Hufty. 2011. Native forests and agriculture in Salta (Argentina): conflicting visions of development. The Journal of Environment and Development 20:251-277. http://dx.doi.org/10.1177/1070496511416915

Silvetti, F., G. Soto, D. M. Cáceres, and D. Cabrol. 2013. ¿ Por qué la legislación no protege los bosques nativos de Argentina?: Conflictos socioambientales y políticas públicas. Mundo agrario 13 (26).

Soille, P., and P. Vogt. 2009. Morphological segmentation of binary patterns. Pattern Recognition Letters 30:456-459. http:// dx.doi.org/10.1016/j.patrec.2008.10.015

The Nature Conservancy (TNC). 2005. Evaluación ecoregional del Gran Chaco. The Nature Conservancy, South American Conservation Region, Buenos Aires, Argentina. [online] URL: http://awsassets.wwfar.panda.org/downloads/dossier.pdf

Torrella, S. A., R. Ginzburg, and L. Galetto. 2015. Forest fragmentation in the Argentine Chaco: recruitment and population patterns of dominant tree species. Plant Ecology 216:1499-1510. http://dx.doi.org/10.1007/s11258-015-0532-2

Torres, R., N. I. Gasparri, P. G. Blendinger, and H. R. Grau. 2014. Land-use and land-cover effects on regional biodiversity distribution in a subtropical dry forest: a hierarchical integrative multi-taxa study. Regional Environmental Change 14:1549-1561. http://dx.doi.org/10.1007/s10113-014-0604-1

Tscharntke T., Y. Clough, T. Wanger, L. Jackson, I. Motzke, I. Perfecto, J. Vandermeer, and A. Whitbread. 2012. Global food security, biodiversity conservation and the future of agricultural intensification. Biological Conservervation 151:53-59. http://dx. doi.org/10.1016/j.biocon.2012.01.068

Unidad de Manejo del Sistema de Evaluación Forestal(UMSEF). 2017. Monitoreo de la superficie de bosque nativo de la República Argentina. Ministerio de Ambiente y Desarrollo sustentable, Buenos Aires, Argentina. 84 p.

Unidad Provincial Coordinadora del Agua (UPCA). 2017. Sitios institutionales. Mapas. [online] URL: https://www.formosa.gob. ar/upca/mapas

Vallejos, M., J. N. Volante, M. J. Mosciaro, L. M. Vale, M. L. Bustamante, and J. M. Paruelo. 2015. Transformation dynamics of the natural cover in the Dry Chaco ecoregion: a plot level geodatabase from 1976 to 2012. Journal of Arid Environments 123:311. http://dx.doi.org/10.1016/j.jaridenv.2014.11.009

van der Hoek, Y., B. Zuckerberg, and L. L. Manne. 2015. Application of habitat thresholds in conservation: considerations, limitations, and future directions. Global Ecology and Conservation 3:736-743. http://dx.doi.org/10.1016/j.gecco.2015.03.010
Villard, M. A., and J. P. Metzger. 2014. Review: beyond the fragmentation debate: a conceptual model to predict when habitat configuration really matters. Journal of Applied Ecology 51:309318. http://dx.doi.org/10.1111/1365-2664.12190

Villarino, S. H., G. A. Studdert, P. Baldassini, M. G. Cendoya, L. Ciuffoli, M. Mastrángelo, and G. Piñeiro. 2017. Deforestation impacts on soil organic carbon stocks in the Semiarid Chaco Region, Argentina. Science of The Total Environment 575:1056 1065. http://dx.doi.org/10.1016/j.scitotenv.2016.09.175

Vos, C. C., P. Berry, P. Opdam, H. Baveco, B. Nijhof, J. O'Hanley, C. Bell, and H. Kuipers. 2008. Adapting landscapes to climate change: examples of climate-proof ecosystem networks and priority adaptation zones. Journal of Applied Ecology 45:17221731. http://dx.doi.org/10.1111/j.1365-2664.2008.01569.x 
Appendix 1. Input data

\section{Forest type map}

We used the forest type map of the Formosa Law (Provincial law \#1552/10) which was originally generated by visual interpretation of Landsat images in 2006 (at a scale of 1:250.000) and validated in-situ (Adámoli et al. 2006, unpublished technical report). We reclassified the forest classes of the original forest map of 2006 into the categories used in the Law 1552/10 (Table A1.1). Forest cover was updated to 2015 by deforested areas converted to agriculture or pastures (Arriaga Velasco-Aceves 2017) with a minimum mapping unit of 5 ha. We thus obtained a forest type map for the year 2015 that was converted to raster format at a $300 \mathrm{~m}$ pixel (Fig. A1.1).

Low forest includes mainly woody communities dominated by Prosopis sp.and presence of others species like Tabebuia nodosa, Geoffroea decorticans and Copernicia alba, among others. Tall forest includes different woody communities, like river margin forest, a semideciduous, seasonal forest located at the side of the rivers in the east of the province. River margin forest has high species diversity with presence of Tabebuia heptaphylla, Cordia americana, Gleditsia amorphoides, Syagrus romanzoffiana, Enterolobium contortisiliquum, among others. Tall forest also includes "quebrachales", a deciduous or semideciduous thorny forest dominated by Schinopsis balansae in the east and S. lorentzii in the west of the province (Prado 1993, Adámoli et al. 2006, unpublished technical report).

Table A1.1. Correspondences between forest categories in the base forest map of 2006, and those used for the application of Formosa Law. TF: Tall forest, LF: Low Forest.

\begin{tabular}{lc}
\hline \hline Adámoli et al. 2006 & Forest type \\
\hline Bosque alto & TF \\
Bosque en cauce autóctono & TF \\
Isletas de bosque alto & TF \\
Bosque bajo & LF \\
Bosque bajo inundable & LF \\
\hline
\end{tabular}




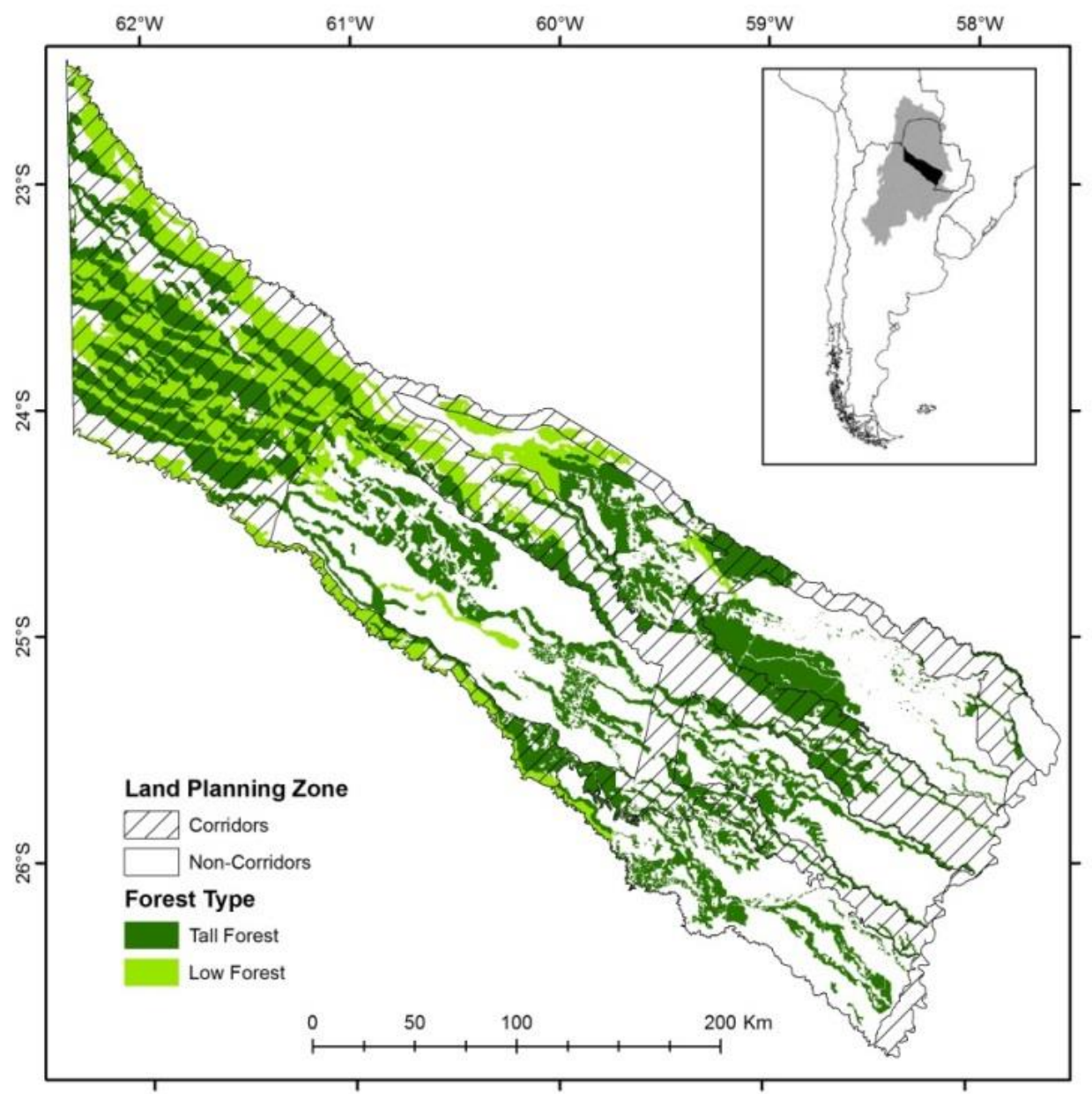

Figure A1.1. Forest-type map used as a base for our spatial simulations.

\section{Cadastral map}

The cadastral division of Formosa is heterogeneous, ranging from very small plots in the east to very big plots and unparceled areas in the west. To obtain a complete cadastral map, in those areas not defined by cadaster plots (e.g. "tierras fiscales"-public lands), we simulated a cadastral division using square grids with the median cadaster-plot size in each department (i.e., the smallest administrative unit in Argentina, comparable to municipalities in the EU and counties in the USA, see inlet in Fig. A1.2). Real cadaster plots cover 4.4 million hectares (58.7\% of the Province surface, Fig. A1.2). We did not consider plots $<100$ ha as these together only make for $0.9 \%$ of the forest and dropping these patches tremendously increased the computational efficiency of our analyses. 


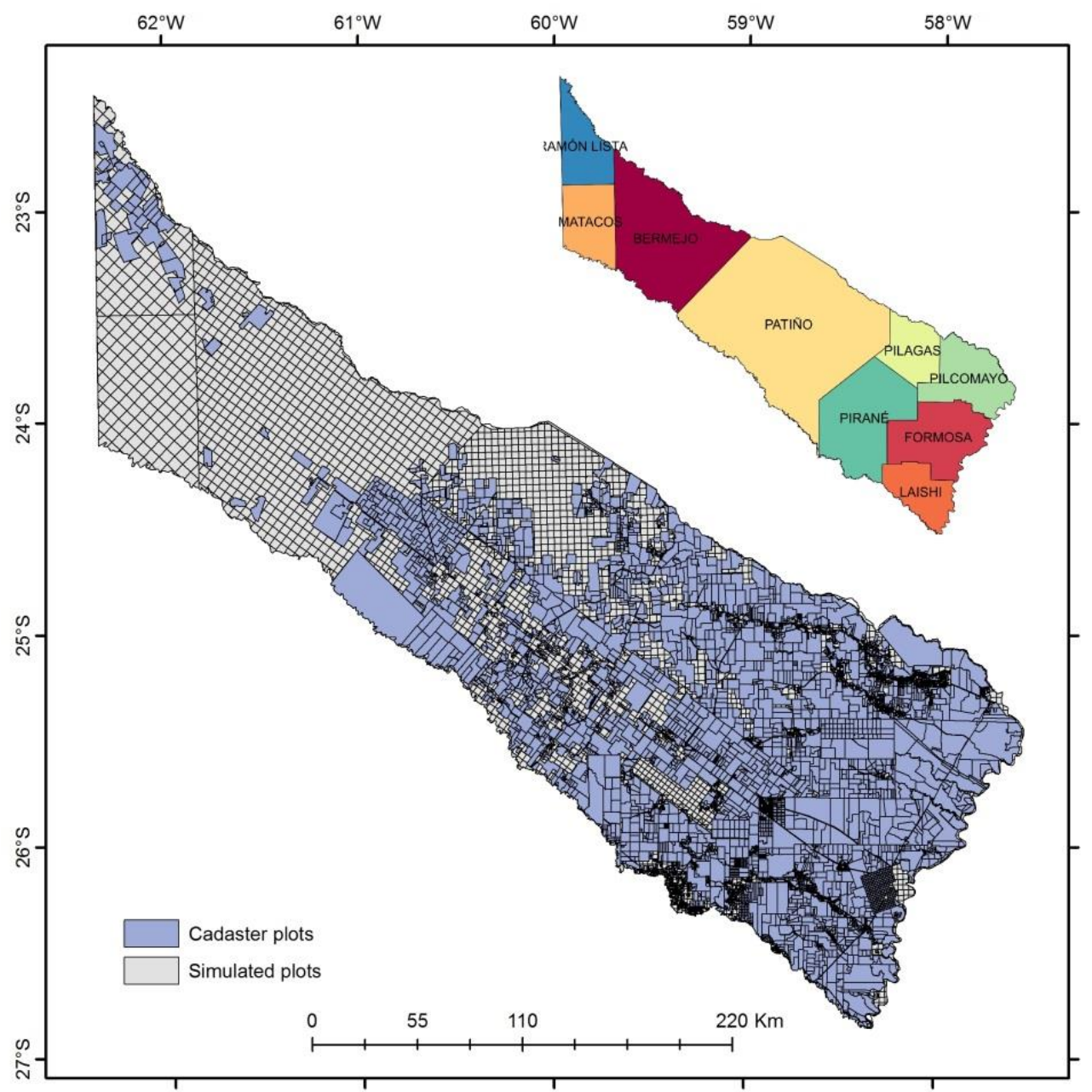

Figure A1.2. Cadaster map with actual and simulated plots used as base for the spatial simulations. Upper right: Administrative division of the province in departments.

\section{Literature cited}

Arriaga Velasco-Aceves 2017. Expansión agropecuaria en la Provincia de Formosa: pérdida de ambientes naturales y fragmentación de bosques entre 2001 y 2015. Tesis de licenciatura. Facultad de Ciencias Exactas y Naturales. Universidad de Buenos Aires.

Prado, D. E. (1993). What is the Gran Chaco vegetation in South America? I: A review. Contribution to the study of flora and vegetaion of the Chaco. V. Candollea 48: 145-172. 
Appendix 2: Allocation of deforested areas for scenarios with low deforestation rate.

To allocate deforestation area under low deforestation rate scenarios, we stratified the province into strata according to the precipitation gradient and land-planning zones (Fig. A2.1). Regarding climate, we divided the province into four zones using an official precipitation map (UPCA 2017) as follows: arid (<600 mm annual precipitation), semiarid $(600-750 \mathrm{~mm})$, sub-humid (750-1200) and humid (>1200 mm). Additionally, sub-humid and humid zones are divided between Corridors and Non-Corridors land planning zones (Fig. A2.1). This results in a total of six strata for scenarios with Corridors, and four strata for scenarios without Corridors (Table A2.1).

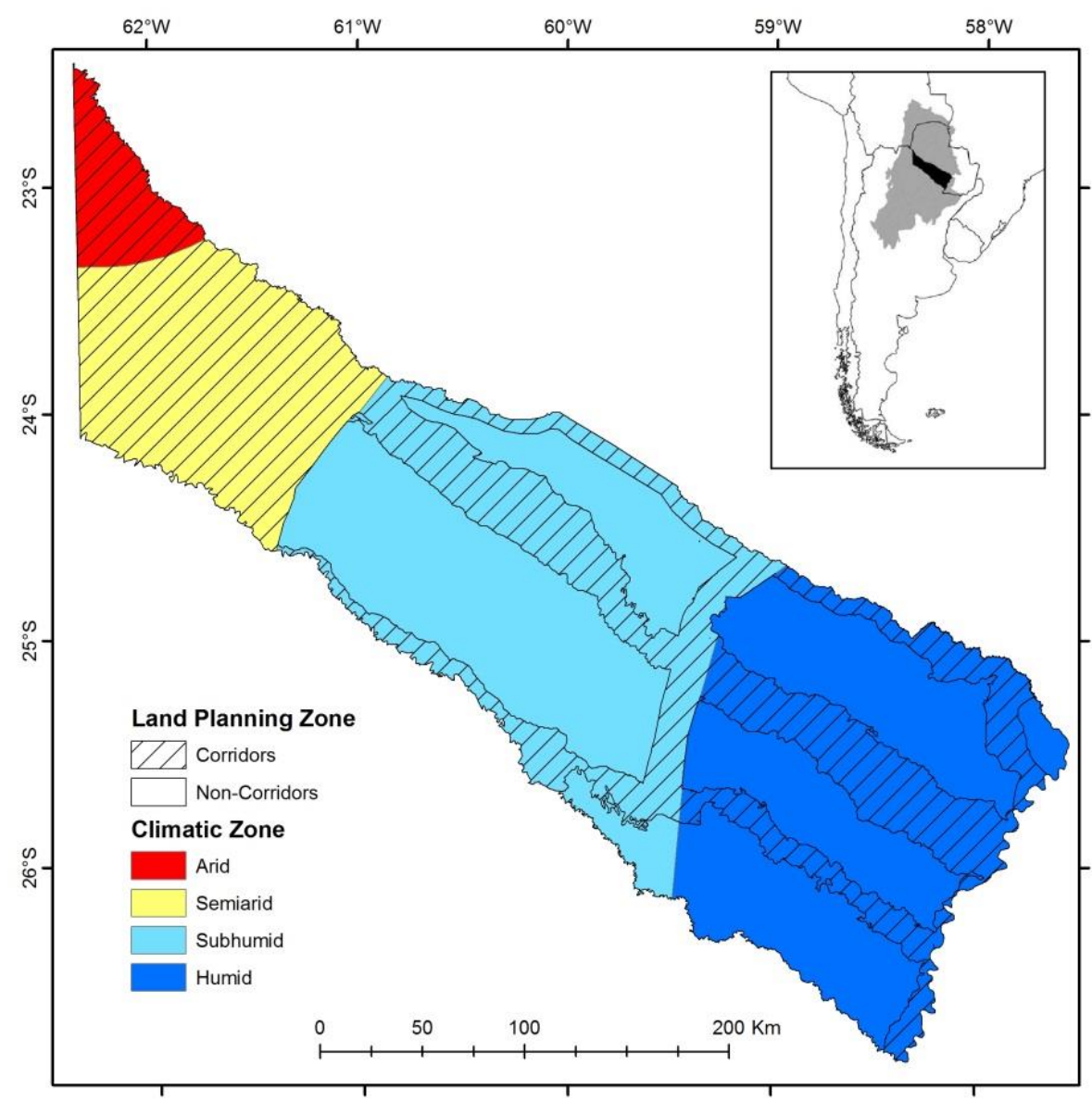

Figure A2.1. Province stratification for the simulation of deforestation according to land planning zones and climatic zones.

The proportion of deforestation for each stratum was established according to that observed in the period 2010-2015 (Arriaga Velasco-Aceves 2017). That is, 4\% of total provincial deforestation was allocated in the humid zone, $69 \%$ in the sub-humid, and $27 \%$ in the semiarid zone. There was no deforestation observed in the arid zone. Regarding land 
planning zones, $75 \%$ of the deforested areas were located in non-corridors zone and $25 \%$ in corridors zones. Using these proportions, we distributed simulated deforested areas (i.e., 400.000 ha) among the strata (Table A2.1).

To reach the deforestation quota in each stratum, we selected plots randomly and sequentially. In each selected plot we removed the total amount of forest area allowed per plot in our scenario quota. The routine stopped when the deforestation quote per strata was reached, but only after completing the deforestation in the last selected plot, which sometimes was slightly over the deforestation quote established. This explains why the deforested area obtained was slightly larger than 400.000 ha, and also the variability between repetitions for the same scenario (Table 2).

Table A2.1. Deforested area in the simulations under scenarios with low deforestation rates in each stratum of the province regarding climatic and land planning zones. In scenarios without corridors there are no land-use planning zones differentiated.

\begin{tabular}{lccc}
\hline \hline & \multicolumn{2}{c}{ With Corridors scenarios } & Without Corridors scenarios \\
Climatic zone & Corridors & Non-Corridors & \\
\hline Arid & 0 & 0 & 0 \\
Semiarid & 108000 & 0 & 108000 \\
Subhumid & 69000 & 207000 & 276000 \\
Humid & 4000 & 12000 & 16000 \\
\hline
\end{tabular}

\section{Literature cited}

Arriaga Velasco-Aceves 2017. Expansión agropecuaria en la Provincia de Formosa: pérdida de ambientes naturales y fragmentación de bosques entre 2001 y 2015. Tesis de licenciatura. Facultad de Ciencias Exactas y Naturales. Universidad de Buenos Aires.

UPCA (Unidad Provincial Coordinadora del Agua) (2017). [online] URL: https://www.formosa.gob.ar/upca/mapas 
Appendix 3. Results and statistical analysis

Table A3.1. Fragmentation and connectivity indices. Scenarios differ in deforestations rates (L: low, H: high), and spatial planning at the regional level (C: with corridors, NC: without corridors) and plot level (D: design, R: random).

\begin{tabular}{|c|c|c|c|c|c|c|c|c|c|c|}
\hline \multirow[t]{2}{*}{ Scenario } & \multicolumn{2}{|c|}{ Number of patches } & \multicolumn{2}{|c|}{ Mean patch size (ha) } & \multicolumn{2}{|c|}{ CONNECT } & \multicolumn{2}{|c|}{ CLUMPY } & \multicolumn{2}{|c|}{ ECA } \\
\hline & Mean & SD & Mean & SD & Mean & SD & Mean & SD & Mean & SD \\
\hline 2015 & 546 & & 3832.12 & & 0.4437 & & 0.9356 & & 2201434 & \\
\hline L-C-D & 1452.96 & 29.18 & 1950.16 & 39.52 & 0.2876 & 0.0045 & 0.9068 & 0.0005 & 1767330 & 22822 \\
\hline L-C-R & 1711.64 & 34.62 & 1652.02 & 33.70 & 0.2535 & 0.0047 & 0.8986 & 0.0004 & 1726884 & 18936 \\
\hline L-NC-D & 1418.6 & 43.48 & 2000.60 & 62.07 & 0.2899 & 0.0072 & 0.9135 & 0.0006 & 1716374 & 23125 \\
\hline L-NC-R & 1706.84 & 45.26 & 1658.24 & 44.53 & 0.247 & 0.0062 & 0.9055 & 0.0005 & 1676408 & 23410 \\
\hline$H-C-D$ & 2493 & & 958.01 & & 0.1883 & & 0.8742 & & 1437464 & \\
\hline $\mathrm{H}-\mathrm{C}-\mathrm{R}$ & 3383.3 & 45.34 & 702.19 & 9.44 & 0.1531 & 0.0016 & 0.8555 & 0.0004 & 1409136 & 6968 \\
\hline H-NC-D & 3426 & & 510.54 & & 0.1376 & & 0.8201 & & 903888 & \\
\hline $\mathrm{H}-\mathrm{NC}-\mathrm{R}$ & 5335.08 & 61.56 & 323.25 & 3.71 & 0.1014 & 0.0011 & 0.7832 & 0.0005 & 616872 & 18408 \\
\hline
\end{tabular}

We made pair-wise comparisons to test for the significance of the differences between scenarios in terms of number of patches, CONNECT, CLUMPY and ECA index values. We checked for normal distribution and used $t$-tests with Satterthwaite correction (Satterthwaite 1946) in those comparisons without homogeneous variances. Results of these tests are reported in Table A3.1. In cases without normal distribution, we used the Mann-Whitney U test. Statistical analyses were made using the software Infostat (Di Rienzo et al. 2017). 
Table A3.2. Statistical results for the comparisons between the indices measuring forest fragmentation (number of patches) and connectivity (CONNECT, CLUMPY, ECA). Scenarios differ in deforestations rate (L: low, H: high), spatial planning at the regional level (C: with corridors, NC: without corridors) and spatial planning at the plot level (D: design, R: random).

\begin{tabular}{|c|c|c|c|c|c|c|c|c|c|c|c|}
\hline \multicolumn{2}{|c|}{ Compared scenarios } & \multicolumn{2}{|c|}{ Number of patches } & \multicolumn{2}{|c|}{ CONNECT } & \multicolumn{2}{|c|}{ CLUMPY } & \multicolumn{4}{|c|}{ ECA } \\
\hline & & $\mathrm{T}$ & $\mathrm{P}$-value & $\mathrm{T}$ & $\mathrm{P}$-value & $\mathrm{T}$ & $\mathrm{P}$-value & $\mathrm{T}$ & $\mathrm{P}$-value & W & P-value \\
\hline L-C-D & L-C-R & $-40,4$ & $<0.0001$ & 37,23 & $<0.0001$ & 89,26 & $<0.0001$ & 9,59 & $<0.0001$ & & \\
\hline L-C-D & L-NC-D & 4,64 & $<0.0001$ & $-1,91$ & 0,0593 & $-62,58$ & $<0.0001$ & & & 3627 & $<0.0001$ \\
\hline L-C-D & L-NC-R & $-33,33$ & $<0.0001$ & 37,46 & $<0.0001$ & 13,68 & $<0.0001$ & 19,67 & $<0.0001$ & & \\
\hline L-C-D & $\mathrm{H}-\mathrm{C}-\mathrm{R}$ & $-253,13$ & $<0.0001$ & 199,25 & $<0.0001$ & 566,59 & $<0.0001$ & 106,15 & $<0.0001$ & & \\
\hline L-C-D & $\mathrm{H}-\mathrm{NC}-\mathrm{R}$ & $-402,96$ & $<0.0001$ & 283,97 & $<0.0001$ & 1192,51 & $<0.0001$ & & & 3775 & $<0.0001$ \\
\hline L-C-R & L-NC-D & 37,28 & $<0.0001$ & $-29,97$ & $<0.0001$ & $-149,32$ & $<0.0001$ & & & 2803 & 0,0135 \\
\hline L-C-R & L-NC-R & 0,6 & 0,5528 & 5,96 & $<0.0001$ & $-71,49$ & $<0.0001$ & 11,78 & $<0.0001$ & & \\
\hline L-C-R & $\mathrm{H}-\mathrm{C}-\mathrm{R}$ & $-207,19$ & $<0.0001$ & 144,41 & $<0.0001$ & 518,96 & $<0.0001$ & 110,37 & $<0.0001$ & & \\
\hline L-C-R & H-NC-R & $-362,78$ & $<0.0001$ & 224,83 & $<0.0001$ & 1187,75 & $<0.0001$ & & & 3675 & $<0.0001$ \\
\hline L-NC-D & L-NC-R & $-32,47$ & $<0.0001$ & 31,89 & $<0.0001$ & 73,74 & $<0.0001$ & & & 3504 & $<0.0001$ \\
\hline L-NC-D & $\mathrm{H}-\mathrm{C}-\mathrm{R}$ & $-221,15$ & $<0.0001$ & 130,99 & $<0.0001$ & 591,44 & $<0.0001$ & & & 3775 & $<0.0001$ \\
\hline L-NC-D & H-NC-R & $-367,47$ & $<0.0001$ & 182,69 & $<0.0001$ & 1182,11 & $<0.0001$ & & & 3775 & $<0.0001$ \\
\hline L-NC-R & $\mathrm{H}-\mathrm{C}-\mathrm{R}$ & $-185,03$ & $<0.0001$ & 103,62 & $<0.0001$ & 531,25 & $<0.0001$ & 77,37 & $<0.0001$ & & \\
\hline L-NC-R & $\mathrm{H}-\mathrm{NC}-\mathrm{R}$ & $-335,78$ & $<0.0001$ & 163,28 & $<0.0001$ & 1146,01 & $<0.0001$ & & & 3775 & $<0.0001$ \\
\hline $\mathrm{H}-\mathrm{C}-\mathrm{R}$ & H-NC-R & $-180,52$ & $<0.0001$ & 187,52 & $<0.0001$ & 754,27 & $<0.0001$ & & & 3775 & $<0.0001$ \\
\hline
\end{tabular}

\section{References}

Di Rienzo J.A., Casanoves F., Balzarini M.G., Gonzalez L., Tablada M., Robledo C.W. InfoStat versión 2017. Grupo InfoStat, FCA, Universidad Nacional de Córdoba, Argentina. URL http://www.infostat.com.ar

Satterthwaite F.E. 1946. An approximate distribution of estimates of variance components. Biometrics Bulletin 2: 110-114. 